\title{
SELECTIVE WEED CONTROL IN PEAS
}

\author{
G. B. Duff and R. W. Moffat \\ Ivon Watkins-Dow Ltd., New Plymouth
}

Summary

\begin{abstract}
Dinoseb and MCPB have been the standard herbicides for weed control in peas for many years despite their various disadvantages. Over the last four years, investigations have shown that prometryne used post-emergence has shown considerable promise with a number of important practical advantages. The results of four trials carried out over the past two seasons are discussed. Prometryne at $0.5 \mathrm{lb}$ and $0.75 \mathrm{lb}$ a.i. per acre has given at least an equal degree of weed control to the standard treatments with satisfactory crop selectivity. Linuron at $0.375 \mathrm{lb}$ a.i. per acre gave satisfactory weed control but the margin of crop tolerance is too limited to warrant widespread use.
\end{abstract}

\section{INTRODUCTION}

THE AREA of peas grown in New Zealand has remained in the vicinity of 35,000 to 40,000 acres for a number of years, threequarters of the total being grown for seed and the remainder for processing. Weed control practices play an important part in the production of the pea crop, as the presence of weeds presents harvesting difficulties, quite apart from any loss which may have occurred owing to competition for moisture and nutrients.

A great number of herbicides have been screened over recent years in an endeavour to improve on the standard treatments, dinoseb and/or MCPB, which have been used extensively over this period. In many areas throughout the country, the standard treatments have failed to give an adeqiate control of redroot (Amaranthus hybridus), cornbind (Polygonum convolvulus), wireweed (Polygonum aviculare), spurrey (Spergula arvensis), and fumitory (Fumaria officinalis)' (Allen, 1964). In addition, the toxicity and hazard to the user of dinoseb and its reliance on temperature conditions for optimum results are well known. There is also a growing need, particularly in process growing areas, for a nonhazardous" crops to the pea-growing areas.

Prior to 1963 a large number of herbicides had been evaluated both as pre- and post-emergent treatments. On a number of occasions, pre-emergent treatments such as simazine and propazine have given excellent annual weed control with satisfactory crop tolerance, but the reliance of these types of materials on adequate moisture and a well prepared seedbed for optimum results makes them impractical for widespread acceptance.

It had become quite obvious that any candidate material for the pea weed control field had to exhibit a number of characteristics to be worthy of further evaluation. Briefly, the herbicide should be a selective material of low mammalian toxicity, with a broad spectrum of weed control when used post-emergence with some additional pre-emergent activity. It has been demonstrated that the earlier the control of weeds in peas the greater "the yield 
response to the treatment (Nelson and Nylund, 1962), and thus a post-emergent treatment at an early stage of the crop is desirable. Screening trials up to this time had indicated that prometryne and linuron were the most likely materials, although the margin between satisfactory weed control and crop tolerance of linuron appeared to be narrow. Small plot and field-scale trials over the past two seasons have been concentrated on the comparison of these two materials against the standard dinoseb and MCPB treatment. The trial results presented indicate the type of responses obtained.

\section{EXPERIMENTAL}

All small plot treatments were applied with a bicycle-mounted logarithmic sprayer to $80 \mathrm{ft} \times 8 \mathrm{ft}$ plots using 25 solid cone nozzles, applying $30 \mathrm{gal}$ of water per acre at $40 \mathrm{lb} / \mathrm{sq}$. in. pressure. The observational trials were replicated four times and the yield trial six times. All rates are expressed in lb of active ingredient per acre and the ratings for weed control are based on a $0-10$ visual scale ( 10 being the maximum effect and 0 the no effect level), the values quoted being the means of observations of two or more persons. Ratings for crop vigour are based on a $0-10$ visual scale (10 being no crop retardation and 0 being complete crop elimination).

\section{RESULTS AND DISCUSSIONS}

TrIAL I (Hawke's Bay, 1963)

The major weeds on the site were redroot, fathen (Chenopodium album), shepherd's purse (Capsella bursa-pastoris), nettle (Urtica urens) and black nightshade (Solanum nigrum). The weeds were at the 4 to 6 true leaf stage, 1 to $2 \mathrm{in}$. high and growing vigorously at the time of treatment. The peas were at the 4 to 6 node stage of growth, the variety being Victory Freezer.

Visual assessment of weed control and crop vigour was made three and seven weeks after application (Table 1).

TABLE 1: VISUAL ASSESSMENT OF WEED CONTROL AND CROP VIGOUR, TRIAL I

\begin{tabular}{|c|c|c|c|c|c|c|c|c|}
\hline \multirow{2}{*}{$\begin{array}{l}\text { Treatment } \\
(l b)\end{array}$} & & & & & \multicolumn{2}{|c|}{$\begin{array}{c}\text { Weed Control } \\
\text { Weeks }\end{array}$} & \multicolumn{2}{|c|}{$\begin{array}{c}\text { Crop Vigour } \\
\text { Weeks }\end{array}$} \\
\hline & & & & & 3 & 7 & 3 & 7 \\
\hline Prometryne 0.75 & $\ldots \ldots$ & 1... & $\ldots . .$. & $\ldots . . .$. & 9.5 & 9.4 & 9.1 & 9.4 \\
\hline Prometryne 1.0 & ....... & ........ & $\ldots . . .$. & ....... & 9.7 & 9.7 & 9.1 & 9.2 \\
\hline Linuron 0.375 & ....... & $\ldots . .$. & ....... & $\ldots . .$. & 9.2 & 8.1 & 9.3 & 9.1 \\
\hline Linuron 0.5 & ........ & $\ldots \ldots$ & $\ldots . .$. & ........ & 9.2 & 8.8 & 7.7 & 8.8 \\
\hline Dinoseb 1.0 & ....... & $\ldots \ldots$ & $\ldots \ldots$ & ........ & 3.0 & 4.6 & 10.0 & 10.0 \\
\hline Dinoseb $0.5 / \mathrm{MCPB} 1.0$ & ........ & ....... & ........ & ....... & 4.4 & 6.1 & 9.5 & 9.5 \\
\hline Untreated control & ........ & $\ldots . .$. & $\ldots \ldots$ & ........ & - & - & 9.8 & 9.0 \\
\hline
\end{tabular}

Both rates of prometryne and linuron gave acceptable weed control. However, the $0.5 \mathrm{lb}$ rate of linuron did noticeably check the crop. The disappointing control by the standard mixture of dinoseb and MCPB was largely due to the rate of application being too low under the conditions at the time of spraying, while the poor result of the dinoseb alone was due to the high proportion 


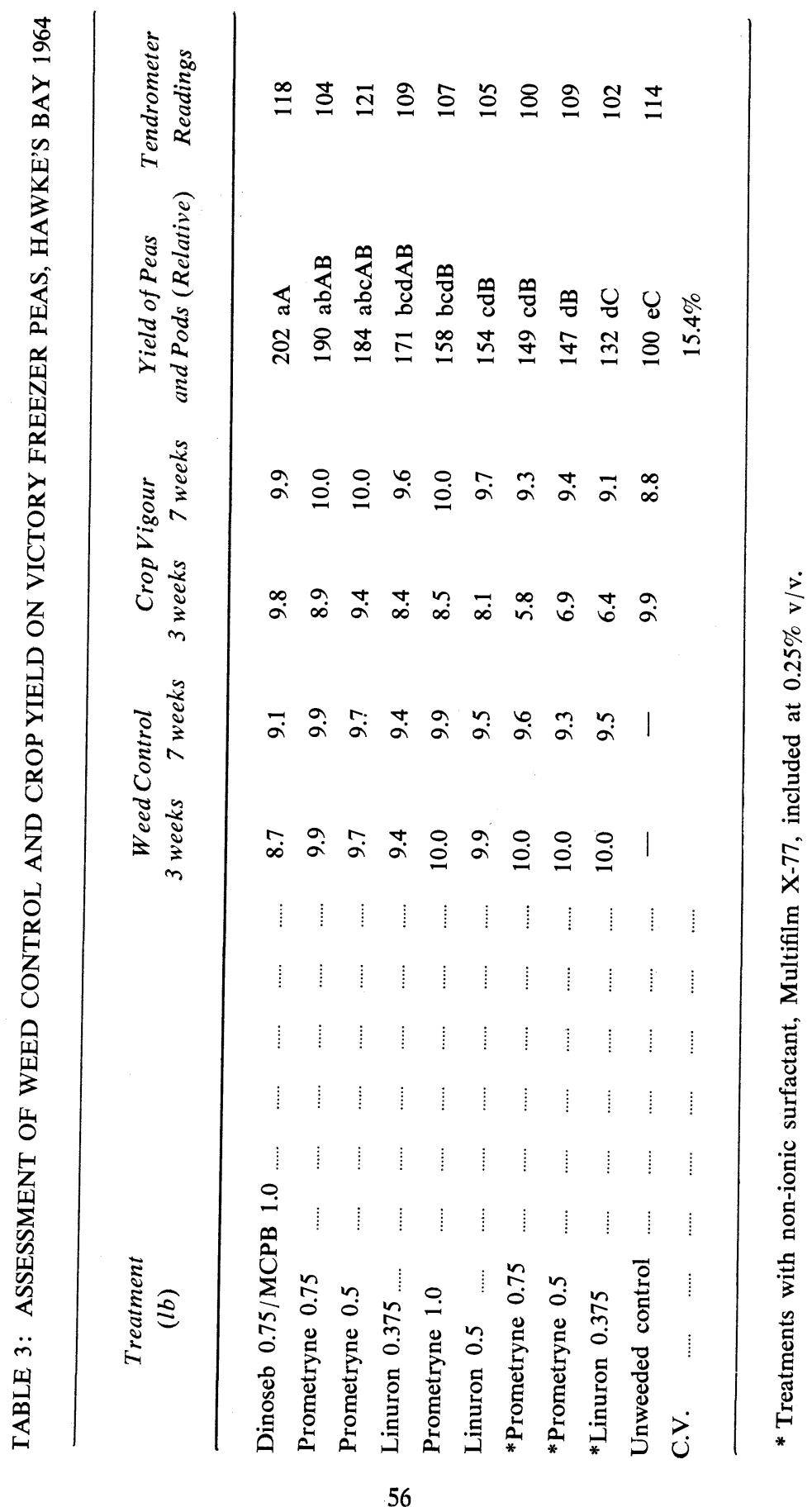


of redroot which was only temporarily checked. In view of the crop suppression given by the higher rate of linuron, it was decided that in futire investigations $0.375 \mathrm{lb}$ per acre would be the maximum rate used.

TRIAL II (Mid Canterbury, 1964)

The following materials and rates were used on a crop of partridge peas. (The major weed was spurrey which was at an advanced stage of growth just prior to flowering): Prometryne at $0.5,0.75$ and $1 \mathrm{lb}$ linuron at $0.375 \mathrm{lb}$ and MCPB at $1.5 \mathrm{lb}$. The control of spurrey $1 \mathrm{lb}$, linuron at $0.375 \mathrm{lb}$ and $\mathrm{MC}$ at $0.75 \mathrm{lb}$ was outstanding. It was also apparent that partridge peas showed less tolerance to linuron and prometryne than garden peas.

TRIAL III (Marlborough, 1964)

The two main weeds present were cornbind and fathen, which were at the 4 to 8 true leaf stage, 2 to 4 in. high and growing vigorwerly under warm moist conditions. At the time of treatment, ously under warm, moist conditions. At the variety being Victory Freezer. Visual assessment for weed control and crop vigour was made five weeks after application (Table 2).

TABLE 2: VISUAL ASSESSMENT OF WEED CONTROL AND CROP VIGOUR, TRIAL III

\begin{tabular}{|c|c|c|c|c|c|}
\hline \multirow{2}{*}{$\begin{array}{l}\text { Treatment } \\
\quad(l b)\end{array}$} & & & \multicolumn{2}{|c|}{ Weed Control } & \multirow{2}{*}{ Crop Vigour } \\
\hline & & & Cornbind & Fathen & \\
\hline Prometryne 0.5 & $\ldots \ldots$ & $\ldots \ldots$ & 5.6 & 9.5 & 9.4 \\
\hline Prometryne 0.75 & $\ldots \ldots$ & $\ldots \ldots$ & 8.5 & 10.0 & 9.0 \\
\hline Prometryne $0.5 / \mathrm{MCPB} 0.75$ & $\ldots \ldots$ & $\ldots \ldots$ & 7.5 & 10.0 & 8.8 \\
\hline Linuron $0.375 / \mathrm{MCPB} 0.75$ & $\ldots$ & $\ldots \ldots$ & 7.4 & 10.0 & 8.8 \\
\hline Dinoseb $0.75 / \mathrm{MCPB} 1.0$ & & $\therefore \ldots .$. & 2.7 & 9.5 & 9.6 \\
\hline Untreated control ...... ...... & $\ldots \ldots$. & $\ldots \ldots$ & - & - & 9.8 \\
\hline
\end{tabular}

Excellent control of cornbind was achieved with prometryne at $0.75 \mathrm{lb}$ and with the MCPB mixtures with prometryne and linuron with satisfactory crop tolerance. The standard treatment of dinoseb with SACPB gave adequate control of fathen although it was ineffecplis MCPB gave adequate control of fathen under these ideal active growth conditions.

Trial IV (Hawke's Bay, 1964)

The main weeds were fathen, redroot, black nightshade and nettle which were at the 2 to 6 true leaf stage, and 1 to 2 in. high at whe time of treatment. The peas, variety Victory Freezer, were in the 6 to 7 node stage and both weed and crop were actively growing. Ratings were made for weed control and crop vigour three and seven weeks after treatment, samples from a 19 sq. $\mathrm{ft}$ area being seven weeks after tret. The crop was harvested seven weeks after taken from each plot. The maturity, the yield of peas pl-is pods was determined and tendrometer readings taken (Table 3 ).

Weed control for all treatments was excellent. The addition of a non-ionic surfactant did not improve the degree of weed control a non-ionic surfactant did not improve the yield from prometryne at $0.75 \mathrm{lb}$ and $0.5 \mathrm{lb}$ was not significantly different from the standard 
TABLE 4: WEED SUSCEPTIBILITY TO STANDARD TREATMENTS FOR PEAS

\begin{tabular}{|c|c|c|c|c|}
\hline & Dinoseb & $M C P B$ & $\begin{array}{c}\text { Dinoseb/ } \\
M C P B\end{array}$ & Prometryne \\
\hline $\begin{array}{l}\text { Black nightshade } \\
\text { (Solanum nigrum) }\end{array}$ & $S$ & MS & $S$ & $S$ \\
\hline $\begin{array}{l}\text { Californian thistle } \\
\text { (Cirsium arvense) }\end{array}$ & $\mathrm{CH}$ & $\mathbf{S}$ & MS & $\mathrm{O}$ \\
\hline $\begin{array}{l}\text { Cornbind } \\
\text { (Polygonum convolvulus) }\end{array}$ & SL & $\mathrm{CH}$ & $\mathbf{S}$ & $S$ \\
\hline $\begin{array}{l}\text { Fathen } \\
\text { (Chenopodium album) }\end{array}$ & $S$ & $\mathbf{S}$ & $\mathrm{S}$ & $S$ \\
\hline $\begin{array}{l}\text { Fumitory } \\
\text { (Fumaria officinalis) }\end{array}$ & $\mathbf{S}$ & $\mathrm{CH}$ & MS & $S$ \\
\hline $\begin{array}{l}\text { Redroot } \\
\text { (Amaranthus hybridus) }\end{array}$ & $\mathrm{CH}$ & $\mathbf{S}$ & $\mathbf{S}$ & $S$ \\
\hline $\begin{array}{l}\text { Redshank } \\
\text { (Polygonum persicaria) }\end{array}$ & $\mathrm{CH}$ & 0 & $\mathrm{CH}$ & $S$ \\
\hline $\begin{array}{l}\text { Spurrey } \\
\text { (Spergula arvensis) }\end{array}$ & SL & $\mathbf{O}$ & SL & $\mathbf{S}$ \\
\hline $\begin{array}{l}\text { Wild turnip } \\
\text { (Brassica campestris) }\end{array}$ & $\mathbf{S}$ & $\mathrm{CH}$ & $\mathrm{S}$ & MS \\
\hline $\begin{array}{l}\text { Nettle } \\
\quad \text { (Urtica urens) }\end{array}$ & SL & $\mathbf{S}$ & $\mathbf{S}$ & $\mathbf{S}$ \\
\hline \multicolumn{5}{|l|}{ WEEDS OF LESS IMPORTANCE } \\
\hline $\begin{array}{l}\text { Chickweed } \\
\text { (Stellaria media) }\end{array}$ & $\mathbf{S}$ & $\mathrm{O}$ & $\mathbf{S}$ & $\mathrm{S}$ \\
\hline $\begin{array}{l}\text { Docks } \\
\text { (Rumex spp.) }\end{array}$ & $\mathrm{CH}$ & $\mathbf{S}$ & $\mathbf{S}$ & $\mathrm{CH}$ \\
\hline $\begin{array}{l}\text { Hedge mustard } \\
\text { (Sisymbrium officinale) }\end{array}$ & $\mathbf{S}$ & $\mathbf{S}$ & $\mathbf{S}$ & MS \\
\hline $\begin{array}{l}\text { Mayweeds } \\
\text { (Matricaria inodora) } \\
(\text { Anthemis cotula })\end{array}$ & SL & 0 & SL & MS \\
\hline $\begin{array}{l}\text { Shepherd's purse } \\
\text { (Capsella bursa-pastoris) }\end{array}$ & $S$ & MS & $\mathbf{S}$ & MS \\
\hline $\begin{array}{l}\text { Speedwell } \\
\text { (Veronica persica) }\end{array}$ & MS & $\mathrm{CH}$ & MS & MS \\
\hline $\begin{array}{l}\text { Twin cress } \\
\text { (Coronopus didymus) }\end{array}$ & $S$ & $\mathbf{S}$ & $\mathbf{S}$ & MS \\
\hline
\end{tabular}

$S=$ Susceptible - killed or controlled till harvest.

MS = Moderately susceptible.

$\mathrm{SL}=$ Satisfactory conditions for good control are limited, reliable field-scale use difficult. $\mathrm{CH}=$ Checked only to allow crop establishment, regrowth of weeds may
interfere with harvest.

$\mathrm{O}=$ No reaction, or check of no benefit.

treatment. Normal harvesting of the untreated control would have been impossible owing to the density of the weed growth. A new strike of healthy seedling weeds in the 2 to 4 leaf stage was present at the time of harvest on all treatments, which indicated that the pre-emergence activity of prometryne even at the highest rate

Field-scale treatments of prometryne under commercial conditions have verified the results obtained with plot trials. Where the 
weeds were young ( 2 to 4 leaf stage) and growing vigorously, $0.5 \mathrm{lb}$ of prometryne has been sufficient for satisfactory weed control. However, where weeds were fairly mature or growing conditions were hard and dry prior to treatment, $0.75 \mathrm{lb}$ has been necessary. Prometryne alone has not controlled resprouts from deep rooted perennials such as Californian thistle (Cirsium arvense) and mature docks (Rumex obtusifolius). The addition of up to $1 \mathrm{lb}$ of MCPB has given adequate perennial weed control without any difficulties in the compatability of the two materials or marked loss in crop tolerance. Peas are temporarily checked after an application of prometryne, the visual symptoms being a marginal chlorosis and browning of the lower leaves but this disappears in 2 to 4 weeks depending on the growth conditions following spraying. This check in growth under satisfactory growing conditions has not decreased yields but can delay maturity up to two days which is of no account for seed production but is of interest in a process crop.

\section{CONCLUSIONS}

Linuron at $0.375 \mathrm{lb}$ has given inferior weed control to prometryne at $0.75 \mathrm{lb}$. In view of the limited crop tolerance, liniron should not be used at rates higher than $0.375 \mathrm{lb}$ which has been insufficient for adequate weed control under certain hard growing conditions. Prometryne has shown at least a two times safety margin on garden peas and $0.5 \mathrm{lb}$ has been satisfactory for weed control under conditions of active growth. Prometryne has given at least comparable results to the standard dinoseb and/or MCPB treatments under a wide range of conditions except where there have been present a high proportion of deep-rooted perennials - here prometryne at $0.75 \mathrm{lb}$ in a mixture with MCPB is necessary. Prometryne at $0.75 \mathrm{lb}$ has given outstanding control of spurrey, a weed not adequately controlled by the standard treatments. In view of its control of a wide spectrum of annual broadleaf weeds, its low toxicity and its independence of temperature conditions, prometryne is undoubtedly a most promising alternative herbicide for weed control in peas and fully justifies firther field-scale evaluation.

The susceptibility of the main weeds occurring in the pea-growing areas to the standard treatments and prometryne is given in Table 4.

\section{ACKNOWLEDGEMENTS}

The authors are indebted to Dr G. W. Mason for assistance in the preparation of this paper and to staff of the Research and Development Department, Ivon Watkins-Dow Ltd., for assistance with the trials.

\section{REFERENCES}

Allen, F. C., 1964: Proc. 17th N.Z. Weed \& Pest Control Conf.: $200-5$

Nelson; Nylund, 1962: Weeds, 10: 224-9. 